\title{
Deprivatization of Disbelief?: Non- Religiosity and Anti-Religiosity in 14 Western European Countries
}

\section{Egbert Ribberink, Peter Achterberg and Dick Houtman}

\author{
Erasmus University Rotterdam
}

\begin{abstract}
This article aims to move beyond media discourse about "new atheism" by mapping and explaining anti-religious zeal among the public at large in 14 Western European countries. We analyze data from the International Social Survey Program, Religion III, 2008, to test two theories about how country-level religiousness affects anti-religiosity and its social bases: a theory of rationalization and a theory of deprivatization of disbelief. Hypotheses derived from the former are contradicted, whereas those derived from the latter are largely confirmed. Anti-religiosity is strongest among disbelievers and among the higher educated in the most religious countries and among the older generations in today's most secularized countries.
\end{abstract}

\section{INTRODUCTION}

"There's probably no God. Now stop worrying and enjoy your life." Buses with these words drove around London and other British cities from the beginning of January 2009. It was the start of a British atheistic campaign, later also launched in the United States, Canada, Australia, New Zealand, Brazil, Italy, Spain, Germany, Ireland, Finland, Sweden, and the Netherlands. Even though these campaigns aroused considerable media attention in most of these countries, this assertive type of "new atheism" and its social and cultural support bases are only beginning to

Address correspondence and reprint requests to: Egbert Ribberink, Department of Sociology, Faculty of Social Sciences, Erasmus University Rotterdam, P.O. Box 1738, 3000 DR Rotterdam, The Netherlands. E-mail: ribberink@fsw.eur.nl; Peter Achterberg, Department of Sociology, Faculty of Social Sciences, Erasmus University Rotterdam, P.O. Box 1738, 3000 DR Rotterdam, The Netherlands. E-mail: peterachterberg@gmail.com; Dick Houtman, Department of Sociology, Faculty of Social Sciences, Erasmus University Rotterdam, P.O. Box 1738, 3000 DR Rotterdam, The Netherlands. E-mail: houtman@fsw.eur.nl 
be explored (Amarasingam 2010). This is because students of religion have traditionally treated "non-religiousness" not so much as a domain of systematic empirical study, but rather as one of speculation. Some assume for instance that the predominant attitude toward religion in today's massively secularized Western European countries is not so much one of hostility, but rather of disinterest (Bruce 2002), whereas others tacitly assume that non-religiosity logically and inevitably manifests itself as rationalist anti-religiosity (Stark, Iannaccone, and Finke 1996).

Remarkably, then, students of religion have made major efforts to compare religious traditions and to study how the latter are shaped and transformed by the historical, social, and cultural circumstances they find themselves in, but a similar sensibility to specificity, particularity and variation is hard to find when it comes to non-religiosity. One consequence is that people without religious beliefs are often referred to as "atheists" (Becker and Vink 1994; Norris and Inglehart 2004, 186), even though research in the United States by the Pew Forum suggests that the latter label has narrower connotations than "non-religiosity." Only about a quarter of those who are non-religious are willing to identify themselves as "atheists" and the remaining three-quarters reject this label. ${ }^{1}$

Ribberink and Houtman (2010) refer to processes of "coming out" as an atheist (Smith 2011) as processes of "deprivatization of disbelief." They note that in the Netherlands more and more disbelievers appear to express anti-religious sentiments on web-blogs and social media and to argue for a removal of religion from politics and the public domain. These disbelievers have, hence, apparently transformed an indifferent "non-religiosity" into an assertive "anti-religiosity." The study of such processes of deprivatization of disbelief necessitates the application of a distinction between private and indifferent "non-religiosity" on the one hand and public and assertive "anti-religiosity" on the other. Such an opening up of the traditional catch-all category of the non-religious "leftovers" for critical empirical scrutiny (Baker and Smith 2009a; 2009b) is especially important, because assertive anti-religiosity has more potential for political mobilization against public manifestations of religion than indifferent non-religiosity.

Against this background, we study how this type of "anti-religiosity" can be explained, with special reference to the role of national religiousness. Our study thus feeds into the more general debate on how religious and secular fundamentalisms and violence shape the late-modern societies of the 21st century (Calhoun, Juergensmeyer, and VanAntwerpen 2011; Achterberg et al. 2009). We focus on Western Europe, because it is 
there that we find on the one hand some of the most massively secularized countries of the world (particularly in the North West, e.g., Scandinavia, United Kingdom, the Netherlands) and on the other hand countries where religion has retained much more of its former foothold (particularly in the South West, e.g., in Catholic countries such as Spain, Portugal, and Italy) (Martin 2005). We start with an elaboration of two theories that both relate anti-religiosity to national religious contexts, the rationalization theory, and the deprivatization theory, but that do so in strikingly different ways. We then discuss our data and measurements, test the relevant hypotheses, and summarize and discuss our findings.

\section{EXPLAINING ANTI-RELIGIOSITY: THEORY AND HYPOTHESES}

There are two major theories that may be able to explain anti-religious attitudes. On the one hand, there is a long intellectual tradition that can be called the "rationalization theory." It understands reason as the ultimate authority and religion as an irrational force, so that the unfolding of the former stimulates not simply non-religiosity, but anti-religiosity (Campbell 1971). On the other hand, we bring forward a strand of theory that we call the "deprivatization theory," which leads to predictions that are diametrically opposed to those that can be derived from the rationalization theory. This is because it understands anti-religiosity as evoked by a massive public presence of religion (Cimono and Smith 2007; Stahl 2010), whereas it associates indifferent non-religiosity with secularized contexts (Taylor 2007, 12-13). In what follows, we discuss both theories in more detail to derive the hypotheses that need to be tested to ascertain their empirical validity.

\section{Anti-Religiosity as the Outcome of Rationalization}

The notions that there is no God and that religion is a false idea have often been grounded in rationalist convictions, central to which is a firm adherence to reason and science, as for instance in Kant, Marx, and Freud. ${ }^{2}$ Campbell (1971) describes how this has led to the development of a range of "rationalist" movements in the 19th and 20th century, with rationalist societies, rationalist papers, rationalist press associations, and so on and so forth. This line of thinking has deeply influenced the social-scientific study of religion, especially in classical sociology, where Durkheim, Weber, and others expected a growing influence of rational thinking in 
modern times to contribute to the demise of religion (Durkheim 1969, 2913; Weber 1991 [1920]). Stark, Iannaccone, and Finke (1996, 436; italics in original) point out that some sociologists refer to rational thinking not only as the reason for why people do not become religious, or stop being religious, but even for becoming anti-religious:

For many leading scholars, religion was not so much a phenomenon to be explained as it was an enemy to be overcome. Starting with the assumption that religion is false, and thus less rational than other behaviors, these scholars employed unique theoretical principles to explain (and dismiss) it and, above all, to pronounce its inevitable demise.

This notion that reason inevitably defines religion as its enemy and will eventually undermine it has meanwhile been extensively critiqued. For one thing, Stark and Finke (1999) have argued against the notion that religion is irrational and cannot be explained rationally. Instead, they refer to rational behavior as the principal reason for why people are religious. For another thing, it has been argued that we increasingly live in a postmodern world, where not only religion, but also science has lost much of its former aura and plausibility (Davie 2007, 95; Houtman and Mascini 2002; Inglehart 1997, 79). Despite these critiques, rationalization theory continues to inform studies aimed at the explanation of disaffiliation from religion until the present day. These studies typically conceive of rationalization and religion as communicating vessels, measuring the former as level of education (at either the individual, country, or historical-period level) and assuming it to be hostile to and undermining the latter (Te Grotenhuis and Scheepers 2001, 594; Baker and Smith 2009a; Need and De Graaf 1996; Ruiter and Van Tubergen 2009).

This rationalization theory has clear implications for where we should expect to find most anti-religiosity. Given the assumed incompatibility of reason and religion, anti-religiosity is seen as the logical outcome of the spread of reason and the concomitant decline of religion, so that disbelievers in the least religious countries should be more anti-religious than disbelievers in more religious ("less rationalized") countries. This informs the hypothesis that in countries with lower levels of religiosity, disbelievers will feature higher levels of anti-religiosity than in countries with higher levels of religiosity (Hypothesis 1).

A central tenet of the rationalization theory is that scientific and technical progress will gradually make the world a more rational place, with the expansion of mass education in the 20th century understood as the major 
vessel of this process. Because rationalization is seen as a gradually but ultimately inevitably unfolding historical process, disaffiliation from religion becomes ever more likely, which shows up in differences in religiosity between birth cohorts (Te Grotenhuis and Scheepers 2001, 603):

This has nothing to do with growing older (an age effect), for it is related to the fact that people born in the 1930s and 1940s experienced much lower levels of rationalization during adolescence compared to people born in the 1970s and 1980s.

Because of its tenet that rationality and religion are incompatible, so that non-religiosity takes the shape of anti-religiosity, the rationalization theory predicts that in countries with lower levels of religiosity (more "rationalized" countries), younger birth cohorts will feature higher levels of antireligiosity than older birth cohorts (Hypothesis 2).

Finally, the assumption that an individual's level of education reflects the degree to which he or she has been exposed to rationalization (Ruiter and Van Tubergen 2009) applies of course particularly if he or she has received his or her education in a less religious ("more rationalized") society. This means that the rationalization theory also predicts that in countries with lower levels of religiosity, the higher educated will feature higher levels of anti-religiosity than the lower educated (Hypothesis 3).

\section{Anti-Religiosity as the Outcome of Deprivatization of Disbelief}

A second explanation of anti-religiosity focuses on religion's power to define what is "normal" and what is "deviant" in more and less religious national contexts. Until the 1960s, in all of the Western European countries under study here, being non-religious was an identity that needed to be defended or at least accounted for. Most Western Europeans were connected to a religious institution of some sort, the church had a major influence on politics and society, and the small number of non-religious people was firmly connected to anti-establishment and anti-religious institutions (McLeod 1997). Being non-religious at the time meant that one had to make a conscious decision to deviate from bourgeois conventions, and this generally meant that one needed to opt for a position that was more anti-religious than non-religious. This has changed since the 1960s and 1970s, when the Christian churches and Christian religion declined in adherence as well as public significance 
in all Western European countries, albeit of course in different degrees. In the process, religion lost much of its former taken-for-granted public role, the discursive power of the religious institutions declined, and being nonreligious became a more viable option, less subject to social sanctions than before. This means that it became easier to adopt a non-religious position that was less necessarily an anti-religious one. In fact, many Western Europeans did not even face the need to actively "choose" to become non-religious any longer, because religion lost its is "natural" and selfevident character, so that it was hardly needed anymore to defend or justify a non-religious position (Taylor 2007, 12).

Our second theory about the relationship between national religious context and anti-religiosity suggests that the existing cross-national variation in the public presence, visibility and vitality of religion does not remain without consequences, but evokes differences pertaining to "deprivatization of disbelief." More specifically, it predicts that disbelievers in countries with low levels of religiosity are less anti-religious than disbelievers in countries like the United States, where religion is virtually omnipresent - a possibility that is at least hinted at in articles by Hout and Fischer (2002), Edgell, Gerteis, and Hartmann (2006), and Baker and Smith (2009b). The deprivatization theory hence predicts that in countries with higher levels of religiosity, disbelievers will feature higher levels of anti-religiosity than in countries with lower levels of religiosity (Hypothesis 4), which is the mirror image of the hypothesis derived above from the rationalization theory.

In this case, too, formative experiences of having grown up in a more religious or a more secular society, do logically make a difference. When someone has been born in the first half of the 20th century, he or she has grown up in a context where most people were a member of a religious institution and where religion had a major influence on culture and politics. In the 1960s, large numbers of young people (who are today's older generation) choose against this and actively disaffiliated from the churches for a wide range of reasons (Streib and Klein 2012). Because of this, today's older birth cohorts will feature higher levels of anti-religiosity than younger ones, because the latter have grown up in a secular context that the former has not experienced during its formative years. Indeed, research by Ecklund and Scheitle (2007) and Sherkat (2008, 542) suggests that this generational difference does not exist in the United States, presumably because it has remained a much more religious country since the $1960 \mathrm{~s}$. Be this as it may, the deprivatization theory predicts that in countries with lower levels of religiosity, older birth cohorts 
will feature higher levels of anti-religiosity than younger birth cohorts (Hypothesis 5). Note that this hypothesis once again contrasts with the hypothesis derived above from the rationalization theory.

Finally, unlike the rationalization theory, the deprivatization theory does not assume that a high level of education is incompatible with religion because of their inherent "rationality" and "irrationality," respectively. What it does assume, is that the high educated will oppose religion and rejected it if it constitutes an obstacle to individual liberty and acceptance of cultural difference. According to any number of studies, after all, a high level of education is one of the major sources of cultural and political tolerance in the Western democracies (Houtman 2003) and there are no good reasons to assume that this is any different for tolerance of religion. Indeed, Bruce $(2002,117)$ suggests that the relativism that is induced by higher education extends to tolerance of religion, so that a high level of education leads not so much to anti-religiosity, but rather to religious indifference. Again in contrast to the rationalization theory, then, the deprivatization theory predicts that in countries with lower levels of religiosity, the higher educated will feature lower levels of anti-religiosity than the lower educated (Hypothesis 6).

\section{Hypotheses}

Both of the theories about anti-religiosity that we have discussed above relate anti-religiosity to national religious contexts, but they do so in strikingly different ways. All three hypotheses derived from each of them are contradicted by the three derived from the other. They predict the highest levels of anti-religiosity for disbelievers as compared to non-disbelievers in respectively the least (rationalization; Hypothesis 1) and the most religious countries (deprivatization; Hypothesis 4). They predict stronger anti-religiosity among respectively the younger (rationalization; Hypothesis 2) and the older generation (deprivatization; Hypothesis 5) in the most secularized countries. Finally, they predict stronger anti-religiosity among the higher than among the lower educated in respectively the least (rationalization; Hypothesis 3) and the most religious countries (deprivatization; Hypothesis 6).

\section{Data and Operationalization}

In order to be able to test these hypotheses, we have used the dataset of the International Social Survey Program: Religion III (ISSP 2008). The ISSP 
2008 dataset is optimal for our research purpose as it contains questions that focus on respondents' attitudes to religion and religious people. As we are interested in anti-religiosity in countries where religion is thought to be disappearing, we focus on Western Europe. In the discussion on the decline of religion in some regions and the resurgence of religion in others, Western Europe is commonly seen as "the odd one out" (Martin 2005, 47; Berger 1999; Greeley 2003). Unlike in other Western countries, such as the United States, in most Western European countries the church has lost most of its former strength, adherence, and influence. This provides a very interesting background for the study of the dynamics of anti-religious attitudes as a product of rationalization or as a deprivatized reaction against religion. For this reason, we selected the data from 14 countries in the ISSP dataset that are located in Western Europe $(N=$ 23,567). These countries are: Austria (AT), Belgium (BE), Denmark (DK), France (FR), Finland (FI), Great Britain (GB), Ireland (IE), the Netherlands (NL), Norway (NO), Portugal (PT), Spain (ES), Sweden (SE), Switzerland $(\mathrm{CH})$, and Germany (DE).

The national church attendance is measured as the share of people going to church at least once a month or more in a particular country.

Anti-religiosity is measured by a scale tapping the respondents' attitudes toward religious influence on public life. Largely based on Bruce (2011, 221) who used the same data, we used four questions that were straightforwardly asking for people's views on the influence religion may have on the public domain. Two of these ask for the attitude of the respondents toward religious leaders influencing government's decisions and peoples' votes. The other two questions ask for response on statements about intolerance of religious people and whether religion creates conflict or not. ${ }^{4}$ We linearly combined the four abovementioned Likert items, with answer categories ranging between 1 (strongly agree) - 5 (strongly disagree), that together yield a reliable scale (Cronbach's $\alpha$ : 0.72 , see Table 1). Normally, the lower scores would indicate agreement with anti-religious sentiments. We reversed this scale, so that higher scores indicate higher levels of anti-religiosity. Scores that were not on the scale of 1-5 were coded as missing.

Disbelief is measured by looking at those people who answered the question what describes best their belief with "I do not believe in God." They were labeled "disbelievers" $(=1)$ and the others were labeled "nondisbelievers" $(=0)$. The latter are not to be called believers, since this group also includes agnostics, people that are not sure what to believe, and those who belief in "a higher being." Between 0\% (Austria) and $5.5 \%$ (Belgium) of respondent were missing on this variable. 
Table 1. Factor and reliability analysis for the anti-religiosity scale

\begin{tabular}{lc}
\hline Questions & $\begin{array}{c}\text { Factor } \\
\text { Loading }\end{array}$ \\
\hline $\begin{array}{l}\text { How much do you agree or disagree that religious leaders should not try to } \\
\quad \text { influence government decisions? }\end{array}$ & 0.79 \\
Religious leaders should not try to influence how people vote in elections & 0.81 \\
Looking around the world, religions bring more conflict than peace & 0.67 \\
People with very strong religious beliefs are often too intolerant of others & 0.66 \\
Eigen value & 2.17 \\
$R^{2}$ & 0.54 \\
Cronbach's $\alpha$ & 0.72 \\
$N$ & 23,567 \\
\hline
\end{tabular}

Source: ISSP 2008.

The different birth cohorts are coded into three groups. People born after 1974 are coded as young (age 15-34 years, 26.5\% of respondents), people born between 1959 and 1973 are coded as middle (age 35-54 years, $36.4 \%$ of respondents), and people born before 1958 are coded old (age $55+$ years, $37.1 \%$ of respondents). Education is measured as the number of years people were enrolled in full-time schooling.

The two theories that can explain anti-religiosity as described above, led to three hypotheses that focus on disbelief, birth cohort, and level of education. Other literature suggests that there are more variables that are related to attitudes toward religion. These are marital status and gender (Bainbridge 2005; Ecklund and Scheitle 2007; Miller and Hofmann 1995; Miller and Stark 2002). Marital status has the values (1) Married (54.2\%), (2) Widowed (7.6\%), (3) Divorced (7.3\%), (4) Separated (1.9\%), (5) Not/Never Married (25.9\%). Of all respondents $3.3 \%$ did not answer this question and were coded as missing. Gender has the values (1) Male (46.4\%) and (2) Female (53.6\%). We use these variables as control variables to test our model.

\section{RESULTS}

Before we start testing our hypotheses, first, we will look at where we can find the highest levels of anti-religiosity. Figure 1 presents the average level of anti-religiosity ( $y$-axis) as a function of the level of national church attendance. 


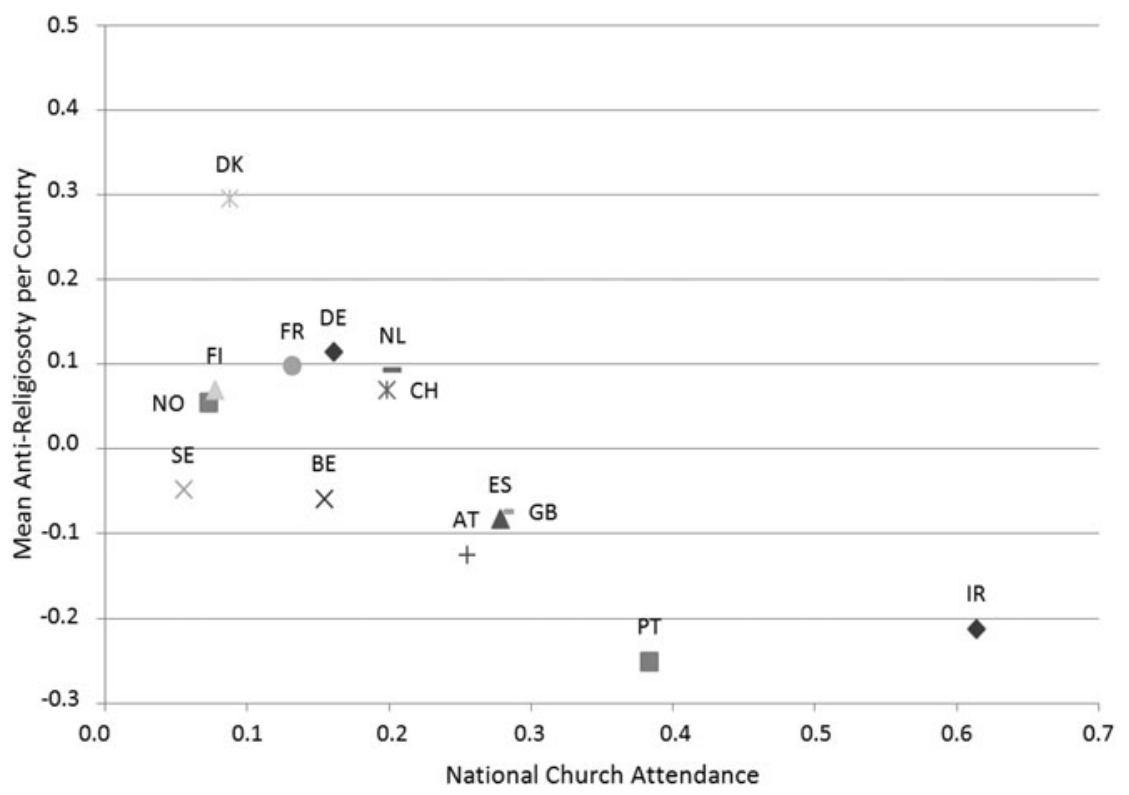

FIGURE 1. Predicted mean anti-religiosity and national church attendance per country for 14 Western European countries, Source: ISSP 2008.

Figure 1 shows that anti-religiosity is most prevalent in the more secularized countries and least prevalent in the highly religious countries. There appears to be a very simple correlation between the level of national church attendance in a certain country and the average anti-religious attitude in that country: The more religious a country is, the higher its religious tolerance and vice versa. This is not surprising. However, even if there is a direct correlation between low levels of national church attendance and anti-religiosity, we have no answer to the question if lower levels of church attendance is the variable that explains anti-religiosity best or if there are other variables that correlate stronger with anti-religiosity. Through a discussion of two theoretical paths, we have come to two sets of opposing hypotheses that helps us answer this question.

We used ordinary least squares linear multilevel analysis with maximum likelihood estimation for two reasons to test these hypotheses. First and foremost, multilevel analysis allows one to simultaneously estimate effects of individual-level variables, and of country-level variables. As our data is structured in such a way that there are two levels, 23,567 individuals with certain characteristics (e.g., birth cohort, disbelief, etc.) 
are nested in 14 countries with certain characteristics (national church attendance); multilevel analysis is the most suited option. Second, as our hypotheses aim at investigating how individuals react differently to different country-level church attendance, multilevel analysis, which allows for the estimation of two equations, one for the main effects and one for the slopes of the effects, is very suited as it allows for testing cross-level interactions. For each set of hypotheses, we ran a separate model estimating so-called fixed effects. These are effects of the variables at either individual or national level, or the interactions between them. Each of the models also contains so-called random effects. These random effects, noted as deviances, are estimations of the variance of the intercept of anti-religiosity which show that the level of anti-religiosity varies across countries. Also, there are estimations of the variances of the slopes of disbelief, age and education showing that the effects of these variables in model 1,2 , and 3 , respectively, vary across countries as well. Unfortunately, the $N$ at the highest, national, level is rather limited (14) so we cannot estimate an unlimited number of covariates in our models. Table 2 shows the results of our analysis, which will be discussed below. ${ }^{5}$

Table 2 shows a number of effects of the variables on anti-religiosity. As said, we included a number of interaction effects, each of them testing another set of opposing hypotheses. To enable interpretation of these effects, we plotted each of these effects in a figure. In Figure 2, we find a visual presentation of the fact that disbelievers have higher levels of anti-religiosity than non-disbelievers. Second, and more importantly, it shows that relative to the non-disbelievers, disbelievers have higher levels of anti-religiosity in the context of high national church attendance. Although it is true that the general level of anti-religiosity in secular countries is higher than in religious countries (which may be predicted by rationalization theory), the effect of religiosity on the anti-religiosity of disbelievers relative to non-disbelievers is more relevant to us (and confirms deprivatization theory). Therefore we confirm Hypothesis 4 (deprivatization) and refute Hypothesis 1 (rationalization).

The second set of opposing hypotheses concerns the relation between the religious context of a country and the influence of birth cohort on anti-religiosity. Here we predicted that if the rationalization theory is right, in a context with low levels of national church attendance, people from younger birth cohorts will have higher levels of anti-religiosity. Deprivatization theory would have it the other way around (higher levels of anti-religiosity for older birth cohorts in context with low 
Table 2. Explaining anti-religiosity (OLS multilevel analysis, Maximum Likelihood, $N=23,567$ in 14 countries)

\begin{tabular}{|c|c|c|c|}
\hline & Model 1 & Model 2 & Model 3 \\
\hline Constant & $0.14 * * *(0.05)$ & $0.20 * * *(0.06)$ & $0.37 * * *(0.06)$ \\
\hline Age low & $-0.04 * *(0.02)$ & $-0.08 \sim(0.05)$ & $-0.03 *(0.02)$ \\
\hline Age medium & $0.03 * *(0.01)$ & $-0.01(0.05)$ & $0.04 * * *(0.01)$ \\
\hline Age old & 0 & 0 & 0 \\
\hline $\begin{array}{l}\text { National church } \\
\text { attendance }\end{array}$ & $-0.57 * *(0.18)$ & $-0.73 * * *(0.20)$ & $-1.47 * * *(0.23)$ \\
\hline Disbelief & $0.29 * * *(0.05)$ & $0.36 * * *(0.01)$ & $0.35 * * *(0.01)$ \\
\hline Education & $-0.01 \sim(0.00)$ & $-0.01 * * *(0.00)$ & $-0.02 * * *(0.00)$ \\
\hline Married & $-0.02 \sim(0.01)$ & $-0.01(0.01)$ & $-0.02 \sim(0.01)$ \\
\hline Widowed & $-0.07 * *(0.02)$ & $-0.06^{*}(0.02)$ & $-0.06 * *(0.02)$ \\
\hline Divorced/separated & $0.05 * *(0.02)$ & $0.06 * *(0.02)$ & $0.05 * *(0.02)$ \\
\hline Unmarried & 0 & 0 & 0 \\
\hline Female & $-0.03 * *(0.01)$ & $-0.03 *(0.01)$ & $-0.03 * *(0.01)$ \\
\hline Male & 0 & 0 & 0 \\
\hline $\begin{array}{l}\text { Disbelief } \times \text { National } \\
\text { church attendance }\end{array}$ & $0.28(0.22)$ & - & - \\
\hline $\begin{array}{l}\text { Age low } \times \text { National } \\
\text { church attendance }\end{array}$ & - & $0.28 \sim(0.19)$ & - \\
\hline $\begin{array}{l}\text { Age medium } \times \\
\text { National church } \\
\text { attendance }\end{array}$ & - & $0.24(0.18)$ & - \\
\hline $\begin{array}{l}\text { Age old } \times \text { National } \\
\text { church attendance }\end{array}$ & - & 0 & - \\
\hline $\begin{array}{l}\text { Education } \times \text { National } \\
\text { church attendance }\end{array}$ & - & - & $0.07 * * *(0.01)$ \\
\hline -2loglikelihood & 41559.77 & 41505.98 & 41514.77 \\
\hline $\begin{array}{l}\text { Deviance individual } \\
\text { level }\end{array}$ & 0.50 & 0.50 & 0.50 \\
\hline Deviance country level & 0.01 & 0.01 & 0.01 \\
\hline $\begin{array}{l}\text { Deviance } \\
\quad \text { disbelief } \times 10^{-2}\end{array}$ & 0.01 & - & - \\
\hline Deviance age $\times 10^{-2}$ & - & 0.01 & - \\
\hline $\begin{array}{l}\text { Deviance } \\
\quad \text { education } \times 10^{-2}\end{array}$ & - & - & 0.01 \\
\hline
\end{tabular}

$\sim p<-0.10 ; * p<0.05 ; * * p<0.01 ; * * * p<0.001$ (one-tailed test for significance).

levels of national church attendance, Hypotheses 2 and 5 respectively). From Table 2 we can see that when we look at the influence of birth cohort on anti-religiosity, we see that it has limited influence. In general, older people tend to be more intolerant toward religion than younger people. In Figure 3, the influence of the variable birth cohort on the predicted anti-religiosity is presented in the context of low and high national church attendance. Here we see that the older birth cohort 


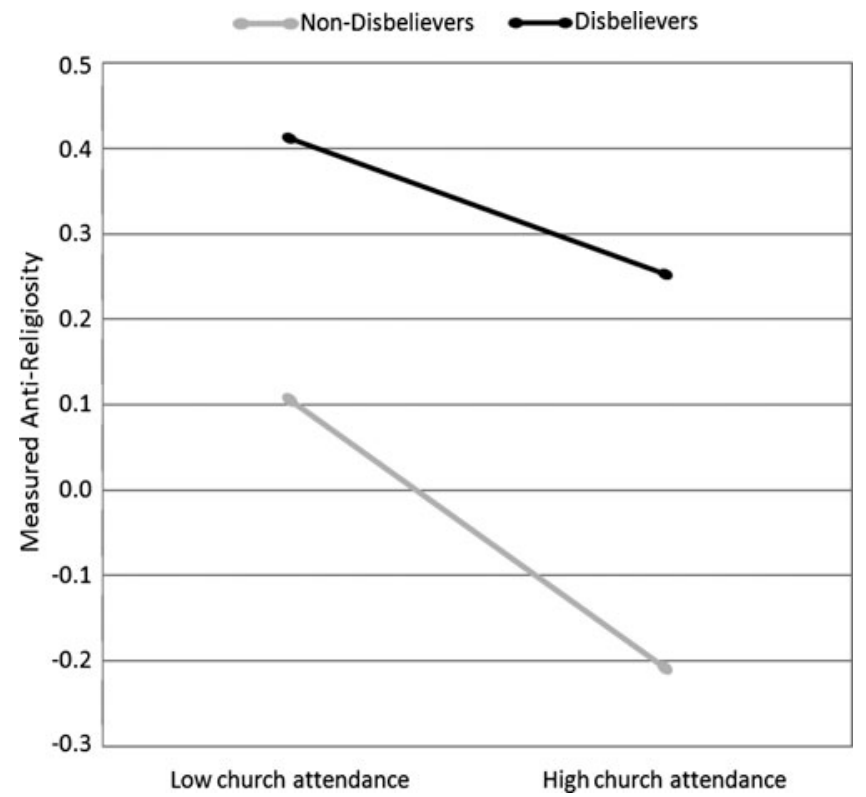

Figure 2. Predicted anti-religiosity for Non-Disbelievers and Disbelievers in contexts of low and high national church attendance in 14 countries, 2008.

is very much affected by the religious context. We see that older cohorts tend to be relatively less anti-religious in a context of high national church attendance. This illustrates how national church attendance is important for analyzing the influence of birth cohorts on anti-religiosity, because the rationalization hypothesis would have had it the other way around. When we compare birth cohorts in the different contexts, we see that the deprivatization hypothesis fits better with our findings. The effect of the religious contexts on the older birth cohorts is as we expected based on the deprivatization theory (disaffiliation of earlier generations leads to higher levels of anti-religiosity in contexts with low levels of national church attendance). It is also in line with the deprivatization theory that younger cohorts would be less anti-religious in contexts with low national church attendance, since they have no need for being intolerant to a religion that they hardly notice. Research done by Ecklund and Scheitle and Sherkat suggested that younger generation are less anti-religious than the middle birth cohorts. This is confirmed by our findings.

The third set of hypotheses predicted the influence of education on antireligiosity. Here we would expect that in a context with low levels of 


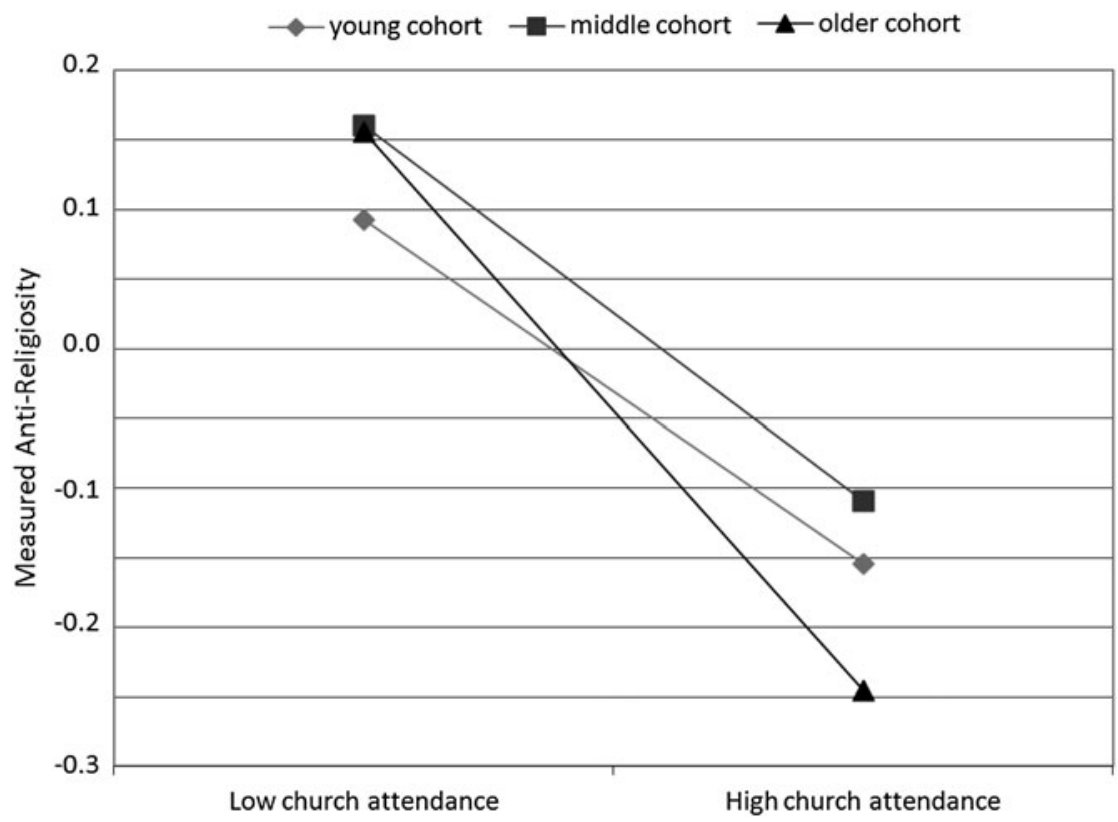

FIGURE 3. Predicted anti-religiosity for three age cohorts in contexts of low and high national church attendance in 14 countries, 2008.

religiosity, people with higher levels of education will be more anti-religious, according to the rationalization theory (Hypothesis 3). Hypothesis 6, derived from the deprivatization theory, says the opposite. Table 2 shows that the variable education in itself does not correlate with anti-religiosity strongly. Looking at the combination of the variable education and national church attendance, however, we see major differences occur. Figure 4, which again illustrates the interaction-term found in the multilevel analysis, shows how higher educated people in a climate of high national church attendance are far more anti-religious than their counterparts in countries with low religiosity. Also, for people with a low level of education, in a country with low levels of national church attendance there is a higher score on level of anti-religiosity, than in countries with higher levels of national church attendance. We see that the religious context has a major impact on how anti-religious people from different levels of education are. Both for the higher educated (who are highly anti-religious in religious contexts, but not in non-religious contexts) as for the lower educated (who are highly anti-religious in non-religious contexts, but not in religious contexts). This influence of religious context on anti- 


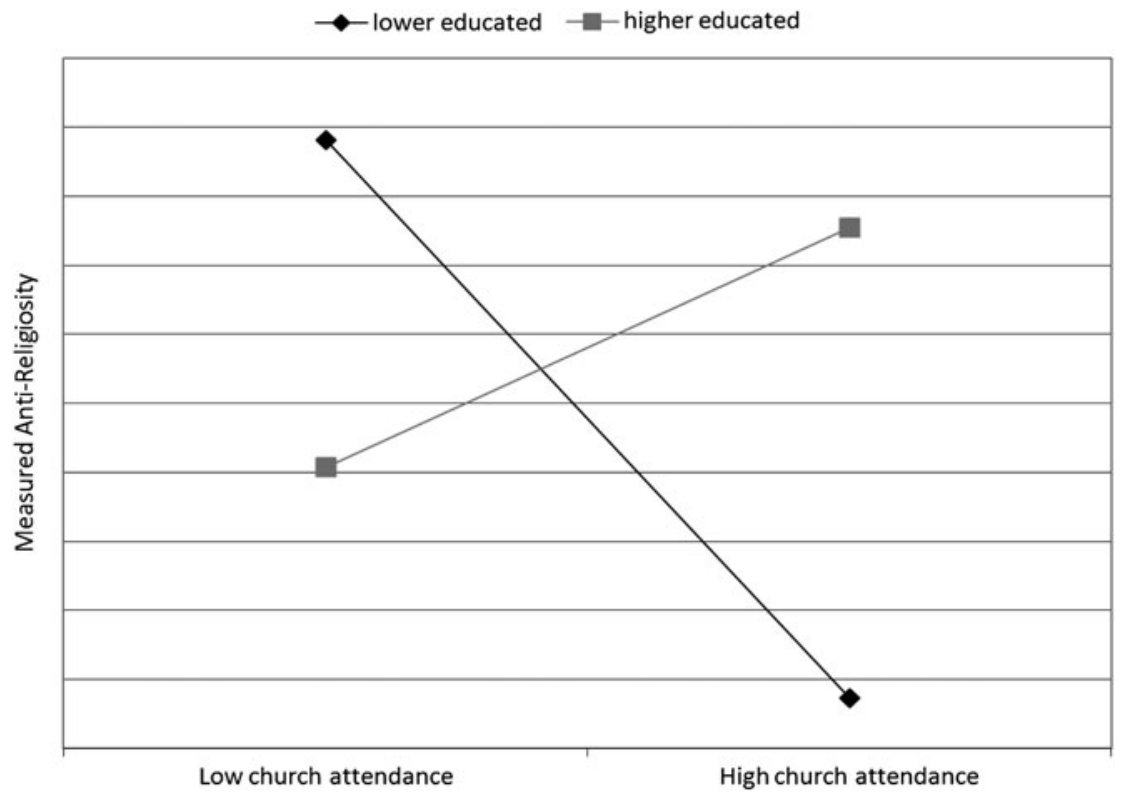

Figure 4. Predicted anti-religiosity for lower educated and higher educated in contexts of low and high national church attendance in 14 countries, 2008.

religiosity of the higher and lower educated is exactly as we expected from the deprivatization theory point of view. Thus Hypothesis 6 (deprivatization) is confirmed and Hypothesis 3 (rationalization) refuted.

To sum up, our analysis shows that all three hypotheses from the deprivatization theory can, by and large, be confirmed and that we did not find much empirical evidence supporting the three rationalization hypotheses. At the same time, this analysis answers the question what conditions will make non-religious more likely to have an anti-religious attitude. Our findings demonstrate that religion matters to disbelievers a lot, but they have relatively higher anti-religiosity rates then non-disbelievers in a context of high religiosity. In the findings on the role of education on anti-religiosity, we discovered that it is the context of high or low levels of religiosity that influences the outcomes significantly.

\section{CONCLUSION}

We started this article with the presentation of atheistic bus campaigns and the debate on "new atheism" that has intensified over the last couple of 
years. However, instead of joining this debate with another opinion, we wanted to address the question on how these anti-religious ideas resonate with the people in the streets of Western Europe. We focused on two theories that brought up a possible explanation for the anti-religious zeal in Western European countries and investigated under what conditions people without religious beliefs will grow an anti-religious attitude. The analysis presented above shows that anti-religiosity does resonate well with people in the streets of Western Europe. However, it does so more, with disbelievers in highly religious contexts, preferably when they are younger and higher educated. In the streets of the countries with lower levels of religiosity, the older, lower educated disbelievers are attracted to anti-religious ideas. The deprivatization theory offered the best theoretical framework to assess these differences. The bottom-line of this theory is that anti-religiosity is not something that comes with either age, disbelief or education, but it is the context of religion that triggers this reaction.

We have focused our attention on Western Europe, but we think that this analysis of anti-religiosity is relevant for the study of what is currently happening in the United States as well. Here, atheists (as a specific group of disbelievers) are seen as immoral and dangerous for the national values (Edgell, Gerteis, and Hartmann 2006), but they are more and more finding ways to establish their identity as a minority over and against the more fundamentalist religious groups (Cimino and Smith 2007; Davie 2007, 95; Hout and Fischer 2002; Stahl 2010). This is a kind of conflict that fits with the politicized "cultural war" idiom that is common usage in the United States (Hunter 1991). Our analysis indicates that anti-religiosity in the first place is a reaction against religion. It would be interesting to see what kind of religion is the trigger in this cultural conflict and if this "cultural war" is something only the higher educated and the cultural elite are part of (like Campbell $(1971,96)$ describes discussing humanism in Britain), or if this is a broader cultural conflict with other social classes in society as well.

For Western Europe, our conclusions are relevant to the debate on the cultural conflicts that arise from what has been called the "twin maladies of modernity" (Achterberg 2006; Houtman, Aupers, and de Koster 2011; Zijderveld 2000). With the falling apart of institutional "plausibility structures" (Berger 1967), more and more people feel alienated and experience a sense of anomie. This has also implications for the non-religious Westerners (Campbell 2007). Our findings show that especially the education one has had influences how people react to this situation. Recently Kronjee and Lampert $(2006,194)$ and Ribberink and Houtman 
(2010, 222) hinted at the possibility that the lower educated would be a new group with anti-religious sentiments in the Dutch society. Our findings confirm these inclinations. More research should be done to exemplify and expand our understanding of this relationship and to find out what exactly motivates the lower educated to take up this intolerant position toward religion. We would expect that it does influence their voting behavior (for example, through anti-Islamic populism), where they want to live (not in areas where people live with other religious values) and how they express themselves online. An example of such a cultural conflict over political and religious identities is the case of Anders Breivik, the Norwegian mass-killer. Although he refers to himself as a Crusader, actually his hatred was pointed toward the (in his words) anti-individualist, pro-Islamic/anti-Jewish, and cultural Marxist/ multicultural politics of Norwegian and European governments and politicians. ${ }^{6} \mathrm{He}$ and other Right-wing extremists position themselves as conservative, Christian as well as Secular Europeans against the influx of Muslim culture. The relation between this anti-religiosity (anti-Islam in this case) and the perceived threat of national and individual identities in a multicultural setting should receive more attention by sociologists. It can help us understand the way our societies accommodate differences in values and opinions, be they religiously or politically inspired.

An interesting expansion of our research would be to see if there is a correlation between the growth of anti-religiosity and the decline of religious adherence over time. We would expect that the outcome of anti-religious action might as well be religious tolerance in some countries as a revival of religion in others (a kind of "purified" religion). Barro and McCleary (2005) demonstrate that the result of the anti-religious agenda of Communism has had a short term effect. Stalin tried to extinguish religion, but 10-15 years after the collapse of the Soviet Union, religion has made a huge comeback in many ex-Soviet countries (Froese 2008; Greeley 2003). The authors of "new atheism" also clearly advocate an anti-religious agenda. Is this anti-religiosity of the higher educated in religious countries a harbinger of a decline in religion? And could this lead toward a situation of non-religion? On the other hand, if it are the younger higher educated disbelievers that become more and more anti-religious, as some authors already noticed for the younger religious groups (Roeland et al. 2010; Stahl 2010), this could lead to serious cultural conflicts as well. Our findings suggest that over time, when the influence of religion decreases, and birth cohorts grow, this might lead to religious tolerance. More longitudinal research should be done to see whether a 
climate of religious intolerance really affects religious growth in a positive or negative way. Also this kind of research can help us to see if there is a tendency towards secular-religious polarization in the more secular countries, or a growing tolerance between religious and non-religious groups.

\section{NOTES}

1. http://pewforum.org/Not-All-Nonbelievers-Call-Themselves-Atheists.aspx (Checked on June 29, 2011).

2. E.g., "The Richard Dawkins Foundation: for reason and science" or the British Humanist Association that promotes an ethical life on the basis of: reason and humanity." See also Kant (1960 [1796]) Religion within the Limits of Reason Alone (translated by Theodore Greene and Hoyt Hudson), New York, NY: Harper and Row; Marx (1844) Contribution to the Critique of Hegel's Philosophy of Law. Introduction, Karl Marx and Frederick Engels, Collected Works, Vol. 3 (London: Lawrence \& Wishart, 1975), 176. See also: Geoghegan, (2004) "Religion and communism: Feuerbach, Marx and Bloch." The European Legacy, 9:585-595; Freud, (1961 [1927]) The Future of an Illusion. New York, NY: Double Day.

3. "Because it becomes more rational, the collective conscience becomes less imperative, and for this very reason, it wields less restraint over the free development of individual varieties." See Casanova (1994) for a further discussion.

4. Bruce $(2011,221)$ used the same four questions, studying sympathy for religions in Britain in 1998 and 2008, but adds two more on tolerance of religious power and confidence in religious organizations. An alternative would be to also include the questions that relate tolerance of religion to the dichotomy between science and faith (questions 11a and 11b), but we follow Greeley (2003) in his concern that these questions are biased and do not measure a general attitude of anti-religiosity but a very specific pro-science attitude. The same counts for the questions that ask for reaction on religious extremists, which is not a general religious phenomenon, but a very specific type of religious practice. Therefore, we chose not to include them in our analyses. Note, however, that additional analysis revealed that inclusion of these items does not make a difference for the results obtained and reported in this article.

5. Even though Denmark and Ireland seem to jump out in Figure 1, removing these countries from our analyses presented here in Table 2 , does not substantially affect the results obtained in this paper. Even without Denmark and Ireland the patterns found in this paper remain generally the same.

6. http://www.scribd.com/doc/60791867/2083-a-European-Declaration-of-Independence, page 828 (Accessed on February 24, 2012).

\section{REFERENCES}

Achterberg, Peter. 2006. Considering Cultural Conflict: Class Politics and Cultural Politics in Western Societies. Maastricht: Shaker Publishers.

Achterberg, Peter, Dick Houtman, Stef Aupers, Willem de Koster, Peter Mascini, and Jeroen van der Waal. 2009. "A Christian Cancellation of the Secularist Truce? Waning Christian Religiosity and Waxing Religious Deprivatization in the West." Journal for the Scientific Study of Religion 48:687-701.

Amarasingam Amarnath. ed. 2010. Religion and the New Atheism. A Critical Appraisal. Leiden: Brill.

Bainbridge, William. 2005. “Atheism.” Interdisciplinary Journal of Research on Religion $1: 1-24$.

Baker, Joseph, and Buster Smith. 2009a. "The Nones: Social Characteristics of the Religiously Unaffiliated.” Social Forces 87:1251-1263. 
Baker, Joseph, and Buster Smith. 2009b. "None Too Simple: Examining Issues of Religious Nonbelief and Nonbelonging in the United States." Journal for the Scientific Study of Religion 48:719-733.

Barro, Robert J., and Rachel M. McCleary. 2005. "Which Countries Have State Religions?" The Quarterly Journal of Economics 120:1331-1370.

Becker, Jos, and René Vink. 1994. Secularisatie in Nederland, 1966-1991: de verandering van opvattingen en enkele gedragingen (Secularization in The Netherlands, 1966-91: The Changes in Convictions and some Behaviors). Den Haag: Sociaal Cultureel Planbureau.

Berger, Peter. 1967. The Sacred Canopy: Elements of a Sociological Theory of Religion. Garden City, NY: Doubleday.

Berger Peter. ed. 1999. The Desecularization of the World: Resurgent Religion and World Politics. Grand Rapids, MI: William B. Eerdmans Publishing Company.

Bruce, Steve. 2002. God is dead: Secularization in the West. Oxford: Blackwell.

Bruce, Steve. 2011. Secularization. In Defence of an Unfashionable Theory. New York, NY: Oxford University Press

Calhoun Craig, Mark Juergensmeyer, and Jonathan VanAntwerpen. eds. 2011. Rethinking Secularism. New York, NY: Oxford University Press.

Campbell, Colin. 1971. Toward a Sociology of Irreligion. London: Macmillan.

Campbell, Colin. 2007. The Easternization of the West: A Thematic Account of Cultural Change in the Modern Era. Boulder, CO: Paradigm.

Casanova, José. 1994. Public Religions in the Modern World. Chicago, IL: Chicago University Press.

Cimino, Richard, and Christopher Smith. 2007. "Secular Humanism and Atheism beyond Progressive Secularism." Sociology of Religion 68:407-424.

Davie, Grace. 2007. The Sociology of Religion. London: Sage.

Durkheim, E. 1969. The Division of Labor in Society. New York, NY: Free Press.

Ecklund, Elaine Howard, and Christopher P. Scheitle. 2007. "Religion among Academic Scientists: Distinctions, Disciplines, and Demographics." Social Problems 54:289-307.

Edgell, Penny, Joseph Gerteis, and Douglas Hartmann. 2006. "Atheists As "'Other": Moral Boundaries and Cultural Membership in American Society." American Sociological Review 71:211-234.

Froese, Paul. 2008. The Plot to Kill God: Findings from the Soviet Experiment in Secularization. Berkeley, CA: University of California Press.

Greeley, Andrew. 2003. Religion in Europe at the End of the Second Millennium. New Brunswick, NJ: Transaction Publishers.

Hout, Michael, and Claude S. Fischer. 2002. "Why More Americans Have no Religious Preference: Politics and Generations." American Sociological Review 67:165-190.

Houtman, Dick. 2003. Class and Politics in Contemporary Social Science: "Marxism Lite” and Its Blind Spot for Culture. New York, NY: Aldine de Gruyter.

Houtman, Dick, and Peter Mascini. 2002. "Why Do Churches Become Empty, While New Age Grows? Secularization and Religious Change in the Netherlands." Journal for the Scientific Study of Religion 41:455-473.

Houtman, Dick, Stef Aupers, and Willem de Koster. 2011. Paradoxes of Individualization: Social Control and Social Conflict in Contemporary Modernity. Aldershot: Ashgate.

Hunter, John D. 1991. Culture Wars: The Struggle to Define America. New York, NY: Basic Books.

Inglehart, Ronald. 1997. Modernization and Postmodernization: Cultural, Economic, and Political Change in 43 Societies. Princeton, NJ: Princeton University Press. 
Kronjee, Gerrit, and Martijn Lampert. 2006. "Leefstijlen en Zingeving (Lifestyles and Meaning)." In Geloven in het Publieke Domein: Verkenningen van een Dubbele Transformatie (English trnaslation here). Amsterdam: Amsterdam University Press.

Martin, David. 2005. On Secularization: Towards a Revised General Theory. Ashgate: Aldershot.

McLeod, Hugh. 1997. Religion and the People of Western Europe 1789-1989. Oxford: Oxford University Press.

Miller, Alan S., and John P. Hoffman. 1995. "Risk and Religion: An Explanation of Gender Differences in Religiosity." Journal for the Scientific Study of Religion 34:63-75.

Miller, Alan S., and Rodney Stark. 2002. "Gender and Religiousness: Can Socialization Explanations Be Saved?" American Journal of Sociology 107:1399-1423.

Need, Ariana, and Nan Dirk De Graaf. 1996. "'Losing My Religion': A Dynamic Analysis of Leaving the Church in the Netherlands." European Sociological Review 12:87-99.

Norris, Pippa, and Ronald Inglehart. 2004. Sacred and Secular: Reexamining the Secularization Thesis. New York, NY: Cambridge University Press.

Ribberink, Egbert, and Dick Houtman. 2010. “'Te ongelovig om atheïst te zijn': Over de Deprivatisering van Ongeloof ('Too Much of a Disbeliever to be an Atheist': On the Deprivatization of Disbelief)." Religie \& Samenleving 5:209-226.

Roeland, Johan, Stef Aupers, Dick Houtman, Martijn de Koning, and Ineke Noomen. 2010. "The Quest for Religious Purity in New Age, Evangelicalism and Islam: Religious Renditions of Dutch Youth and the Luckmann Legacy." Annual Review of the Sociology of Religion 1:289-306.

Ruiter, Stijn, and Frank van Tubergen. 2009. "Religious Attendance in Cross-National Perspective: A Multilevel Analysis of 60 Countries." The American Journal of Sociology 115:863-895.

Sherkat, Darren E. 2008. "Beyond belief: Atheism, Agnosticism, and Theistic Certainty in the United States." Sociological Spectrum 28:438-459.

Smith, Jesse M. 2011. "Becoming an Atheist in America: Constructing Identity and Meaning from the Rejection of Theism." Sociology of Religion 72:215-237.

Stahl, William. 2010. "One-Dimensional Rage: The Social Epistemology of the New Atheism and Fundamentalism." In Religion and the New Atheism: A Critical Appraisal. Leiden: Brill.

Stark, Rodney, Laurence R. Iannaccone, and Roger Finke. 1996. "Religion, Science, and Rationality." American Economic Review 86:433-437.

Stark, Rodney, and Roger Finke. 1999. Acts of Faith: Explaining the Human Side of Religion. Los Angeles, CA: University of California Press.

Streib, Heinz, and Constatin Klein. 2012. "Atheists, Agnostics, and Apostates." In APA Handbooks in Psychology: APA Handbook of Psychology, Religion and Spirituality. Washington DC: American Psychological Association.

Taylor, Charles. 2007. A Secular Age. Harvard, CA: Harvard University Press.

Te Grotenhuis, Manfred, and Peer Scheepers. 2001. "Churches in Dutch: Causes of Religious Disaffiliation in the Netherlands, 1937-1995." Journal for the Scientific Study of Religion 40:591-606.

Weber, Max. 1991 [1920-1921]. From Max Weber: Essays on the Sociology of Religion. Trans. H.H. Gerth and C.W. Mills. Abingdon: Routledge.

Zijderveld, Anton C.. 2000. The Institutional Imperative: The Interface of Institutions and Networks. Amsterdam: Amsterdam University Press. 